\title{
The community structure of Prosobranchia (Mollusca: Gastropoda) on shallow soft bottoms of the Çanakkale Strait
}

\section{Çanakkale Boğazı kıyısal sularının yumuşak zeminleri’ndeki Prosobranş (Mollusca: Gastropoda) kommunite yapısı}

\author{
Seçil Acar* • A. Suat Ateş \\ Çanakkale Onsekiz Mart University, Faculty of Marine Sciences and Technology 17100 Çanakkale, Turkey
}

*Corresponding author: secilkolsal@gmail.com

How to cite this paper:

Acar, S. \& Ateş, A.S. (2017). The community structure of Prosobranchia (Mollusca: Gastropoda) on shallow soft bottoms of the Çanakkale Strait. Ege Journal of Fisheries and Aquatic Sciences, 34(1): 93-101. doi:10.12714/egejfas.2017.34.1.13

\begin{abstract}
The goal of this study was to determine the community structure belonging to the Prosobranchia (Gastropoda, Mollusca) in soft bottoms of the Çanakkale Strait coastal waters $(0-5 \mathrm{~m})$. Benthos samples were collected seasonally using a 30x30 quadrate operated by a SCUBA diver between July 2008 and April 2009. Samplings were carried out at 3 transect depths of 8 different locations of the Çanakkale Strait. A total of 4472 specimens of Prosobranchs were recorded. Rissoa splendida Eichwald, 1830 was the numerically dominant species ( $\mathrm{Di} \%=20.57$ ). Kilitbahir location had the highest number of individuals $(1069)$, while the Lapseki location had the lowest number (157). According to Spearman's rank correlation, the highest positive correlation $(r s=0.75)$ was between salinity and species number. Conversely, the lowest correlation $(r s=0.51$ ) was found between $\mathrm{pH}$ and species number. Bray-Curtis similarity index showed that summer and winter periods were very similar $(88.65 \%)$. Çanakkale and the Kilya inlet points had the highest similarity $(70.87 \%)$.
\end{abstract}

Keywords: Prosobranchia (Gastropoda), community structure, soft bottom, Çanakkale Strait, Turkish Strait System

Öz: Çalışmanın amacı Çanakkale Boğazı kıyısal sularııı (0-5 m) yumuşak zeminlerindeki Prosobranş kommunite yapısını belirlemekti. Bentoz örnekleri Temmuz 2008 ve Nisan 2009 tarihleri arasında bir Scuba dalıcı tarafindan $30 \times 30 \mathrm{~cm}$ 'lik kuadrat kullanılarak mevsimsel olarak toplanmıştı. Örneklemeler Çanakkale Boğazı'nın 8 farklı istasyonun 3 transekt derinliğinde yürütülmüştür. Prosobranşlardan toplam 4472 birey kaydedilmiştir. Rissoa splendida Eichwald, 1830 sayısal olarak en baskın türdü (Di \% = 20.57). Lapseki istasyonu en düşük birey sayısına (157) sahipken, Kilitbahir en yüksek (1069) birey sayısına sahipti. Spearman korelasyonuna göre en yüksek pozitif ilişki $(r s=0.75$ ) tuzluluk ile tür sayısı arasındadır. Aksine en düşük ( $r s=0.51$ ) ilişki ise $\mathrm{pH}$ ile tür sayısı arasındadır. BrayCurtis benzerlik analizi yaz ve kış aylarının (88.65\%) çok benzer olduğunu göstermektedir. Çanakkale ve Kilya koyu istasyonları yüksek (70.87 \%) benzerliğe sahipti.

Anahtar kelimeler: Prosobranş (Gastropod), kommunite yapısı, yumuşak zemin, Çanakkale Boğazı, Türk Boğazlar Sistemi

\section{INTRODUCTION}

Sedimentary bottoms are the key elements of the marine ecosystem. Soft bottom macrobenthos plays significant roles in the marine ecosystem processes such as metabolism of pollutants, nutrient cycling, distribution and production (Snelgrove, 1998). Marine communities are determined by the intrinsic characteristics of populations (biomass, abundance, diversity), functioning of communities as food web, functional diversity and community macro-ecological characteristics (Dimitriadis and Koutsoubas, 2008). Benthic molluscs are a fundamental component of macrofauna and play a major role in biodiversity and community structure (Zenetos, 1996; Koutsoubas et al., 2000). Marine gastropods show different diet types, including deposit and suspension feeding, grazing, parasitism, and predation thus could be found through several trophic levels in the community (Taylor, 1980). Specification of the spatial distribution in species is essential to understand the structure of communities (Hoey et al., 2004). Among the parameters controlling the coastal soft-bottom benthic communities, sediment characteristics were regarded as paramount (Grillo et al., 1998) besides several physicochemical and biological factors. Because of the complexity of the environment, it is difficult to determine the exact parameter affecting the invertebrates (Feld and Hering, 2007). The structure of benthic marine communities is highly variable both spatially and temporally (Kelaher and Levinton, 2003). Therefore, establishing which factors control the biodiversity in nature has long been an important theme of research in ecology (Huston, 1994). The purpose of the present study was to describe the seasonal variations in diversity and community structure of benthic prosobranch gastropods found in the 
Çanakkale Strait with variations in the characteristics of softbottom sediment and environmental variables.

\section{MATERIALS AND METHODS}

\section{Study area}

Eight locations were sampled in the Çanakkale Strait (Fig.1). Geographic coordinates were as fallows: Gelibolu (loc. 1, 40 $40^{\prime} 617^{\prime \prime N} 26^{\circ} 66^{\prime} 692^{\prime \prime E}$ ), Lapseki (loc. 2, 40³4'661"N $26^{\circ} 67^{\prime} 985^{\prime \prime E}$ ), Çanakkale (loc. 3, 40¹5'474" N 2640'879" E), Kilya Inlet (loc. 4, 40²0'472"N 26³6'117"E), Eceabat (loc. 5 $40^{\circ} 18^{\prime} 253^{\prime \prime} \mathrm{N} 26^{\circ} 36^{\prime} 046^{\prime \prime} \mathrm{E}$ ), Kilitbahir (loc. 6, 40¹5'048"N $26^{\circ} 37^{\prime} 878^{\prime \prime E}$ ), Kepez Harbour (loc. 7, 40¹0'360"N $26^{\circ} 37^{\prime} 339^{\prime \prime E}$ ) and Dardanos (loc. 8, 40 $07^{\prime} 493^{\prime \prime} \mathrm{N}$ $\left.26^{\circ} 35^{\prime} 806^{\prime \prime} \mathrm{E}\right)$. Three transects with three different depths $(0.5$, 2 , and $4 \mathrm{~m}$ ) were sampled at each location and one quadrat for each depth in July 2008, November 2008, February 2009, and April 2009 by means of a frame quadrat system of $30 \times 30 \mathrm{~cm}$ (the area was $0.09 \mathrm{~m}-2$ ). Sea water temperature, salinity, $\mathrm{pH}$ and dissolved oxygen were measured in situ using a portable multiparametric instrument YSI 556 (Yellow Springs Instruments). Benthos samples were sieved through a $0.5 \mathrm{~mm}$ mesh size sieve and then the samples were preserved in formaldehyde-seawater solution of $4 \%$.

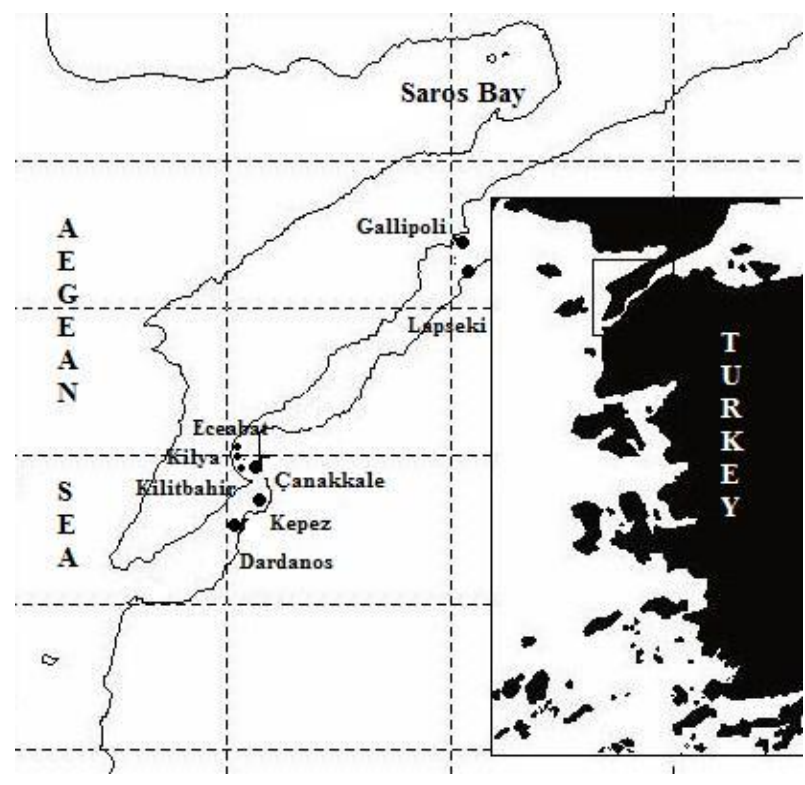

Figure 1. Map showing sampling locations in the Çanakkale Strait

\section{Laboratory analysis}

In the laboratory, gastropods were picked under a stereomicroscope and then preserved in $70 \%$ ethanol. Determination of specimens was performed using a stereomicroscope and identification followed Graham (1971), Nordsieck (1977), Barash and Danin (1992), Sabelli (1992), Cachia et al. (1996; 2001) and Butakov et al. (1997). The classification of gastropoda to the upper categories was conducted according to Bouchet and Roccroi (2005). Sediment granulometry was made using a series of sieve set ranging from $63 \mu \mathrm{m}$ to $20 \mathrm{~mm}$ and sediment particle size was classified according to Buchanan (1984) (Table 1).

Table 1. Sediment analysis classification

\begin{tabular}{ccc}
\hline Particle size $(\mathrm{mm})$ & & Class of sediment \\
$Q_{50}>63 \mathrm{~mm}$ & Boulder \\
$4>Q_{50}>4 \mathrm{~mm}$ & & Cobbles \\
$2>Q_{50}>2 \mathrm{~mm}$ & Gravels \\
$1>Q_{50}>1 \mathrm{~mm}$ & & Very coarse sand \\
$0,5>Q_{50}>0.25 \mathrm{~mm}$ & & Coarse sand \\
$0,25>Q_{50}>0.125 \mathrm{~mm}$ & & Medium sand \\
$0,125>Q_{50}>0.063 \mathrm{~mm}$ & & Fine sand \\
$Q_{50}<0.063 \mathrm{~mm}$ & & Very fine sand \\
& Silts and clays \\
\hline
\end{tabular}

\section{Statistical analysis}

Number of species $(\mathrm{S})$, total abundance $(\mathrm{N})$, dominance index (Di), frequency index (f), Shannon-Wiener diversity index $\left(H^{\prime}\right)$ (Shannon and Weaver, 1963), and Pielou's evenness index (J') (Pielou, 1966) were calculated for each sampling point seasonally. Relationships between the abundance and the environmental factors were analysed by non-metric Multi Dimensional Scaling (MDS). Spatial and seasonal biotic similarity was measured according to the Bray-Curtis index values based on the species density. One-way ANOSIM permutation test was used to determine whether there were significant differences between groups of samples or not. SIMPER analysis was used to identify the contribution of each species to the similarity of the groups identified from the cluster analysis. Spearman's correlation coefficient analyses were used to determine relationship between environmental variables and parameters of the gastropod community. Statistical analysis was done by a combination of IBM SPSS Statistic 20, Minitab 16 and PAST Statistical Program.

\section{RESULTS}

\section{Abiotic data}

Seasonal differences in salinity, temperature and dissolved oxygen were observed during the study. Mean salinity was $25.52 \pm 1.30 \%$ o for the whole sampling area. Dardanos had the highest value $(28.87 \pm 0.95 \% 0)$ and the Lapseki had the lowest value (24.55 $\pm 1.79 \% 0)$. Mean temperature value was measured as $16.02 \pm 0.28{ }^{\circ} \mathrm{C}$. Kilya Inlet had the highest temperature value $\left(26.77^{\circ} \mathrm{C}\right)$ while the lowest value was at Gelibolu $\left(8.87^{\circ} \mathrm{C}\right)$. The mean value of dissolved oxygen (DO) concentration was $7.13 \pm 0.59 \mathrm{mg} \mathrm{L}-1$. Çanakkale site had the highest DO (9.79 mg L-1 in April 2009) while Lapseki was found to have the lowest DO (3.68 mg L-1) in July 2008 (Table 2). 
Table 2. Values of the physical and chemical variables measured in each location seasonally

\begin{tabular}{|c|c|c|c|c|c|c|c|c|c|c|c|c|c|c|c|c|}
\hline \multirow[b]{2}{*}{ Stations } & \multirow[b]{2}{*}{$\begin{array}{l}\mathrm{O}_{2} \\
\mathrm{mg} \mathrm{l}^{-1}\end{array}$} & \multicolumn{4}{|c|}{ July 2008} & \multicolumn{2}{|c|}{ November 2008} & \multicolumn{2}{|c|}{ Paramet } & \multicolumn{4}{|c|}{ February 2009} & \multicolumn{3}{|c|}{ April 2009} \\
\hline & & $\begin{array}{l}\mathrm{T} \\
\left({ }^{\circ} \mathrm{C}\right) \\
\end{array}$ & $\begin{array}{l}\text { S } \\
(\% 0) \\
\end{array}$ & $\mathrm{pH}$ & $\begin{array}{l}\mathrm{O}_{2} \\
\mathrm{mg} \mathrm{l}^{-1}\end{array}$ & $\begin{array}{l}\mathrm{T} \\
\left({ }^{\circ} \mathrm{C}\right) \\
\end{array}$ & $\begin{array}{l}\text { S } \\
(\% 0)\end{array}$ & $\mathrm{pH}$ & $\begin{array}{l}\mathrm{O}_{2} \\
\mathrm{mg} \mathrm{l}^{-1}\end{array}$ & $\begin{array}{l}\mathrm{T} \\
\left({ }^{\circ} \mathrm{C}\right)\end{array}$ & $\begin{array}{l}\text { S } \\
(\% 0)\end{array}$ & $\mathrm{pH}$ & $\begin{array}{l}\mathrm{O}_{2} \\
\mathrm{mg} \mathrm{l}^{-1}\end{array}$ & $\begin{array}{l}\mathrm{T} \\
\left({ }^{\circ} \mathrm{C}\right)\end{array}$ & $\begin{array}{l}\text { S } \\
(\% 0)\end{array}$ & $\mathrm{pH}$ \\
\hline Çanakkale & 4.19 & 23.7 & 23.3 & 8.21 & 5 & 15.25 & 25.6 & 8.32 & 9.63 & 9.18 & 27.8 & 5.3 & 9.79 & 14.26 & 24.4 & 7.07 \\
\hline Lapseki & 3.68 & 24.57 & 22.6 & 8.15 & 3.34 & 15.7 & 24.6 & 8.25 & 9.65 & 9.31 & 27.4 & 6.4 & 8.72 & 13.68 & 23.6 & 6.85 \\
\hline Gelibolu & 5.58 & 25.03 & 22.8 & 8.33 & 5.56 & 16.17 & 25.5 & 8.51 & 9.61 & 8.87 & 27.6 & 7.48 & 8.13 & 13.1 & 24.3 & 6.5 \\
\hline Kilya Inlet & 8.46 & 26.77 & 23.1 & 8.53 & 5.9 & 16.3 & 25.7 & 8.55 & 9.25 & 9.24 & 26.5 & 7.55 & 7.95 & 13.5 & 23.3 & 6.48 \\
\hline Eceaba & 7.4 & 25.6 & 22.9 & 8.39 & 6.01 & 16.01 & 25.5 & 8.46 & 9.56 & 9.24 & 27.4 & 8.09 & 8.9 & 13.31 & 24.2 & 6.52 \\
\hline Kilitbahir & 5.16 & 25.1 & 23.1 & 8.31 & 5.68 & 16.37 & 25.6 & 8.33 & 9.2 & 9.12 & 27.6 & 8.79 & 8.9 & 13.23 & 24.3 & 7.05 \\
\hline Kepez Harbour & 5.14 & 24.39 & 23.5 & 8.3 & 5.28 & 16.22 & 26.1 & 8.45 & 5.68 & 9.65 & 28.3 & 5.44 & 8.65 & 14.1 & 24.8 & 6.74 \\
\hline Dardanos & 6.49 & 24.36 & 28.1 & 8.44 & 5.83 & 16.07 & 30.5 & 8.7 & 7.94 & 9.61 & 28.3 & 5.13 & 8.04 & 15.75 & 28.6 & 6.88 \\
\hline
\end{tabular}

\section{Sediment characteristics}

Sediment particle size analysis was carried out for the samples taken from each location. Particle diameter at the Çanakkale Strait, Kepez, Lapseki, Dardanos, Kilitbahir, Eceabat, Kilya Inlet and Gelibolu was $1.027 \mathrm{~mm} ; 1.046 \mathrm{~mm}$;
$0.342 \mathrm{~mm} ; 0.235 \mathrm{~mm} ; 0.636 \mathrm{~mm} ; 0.364 \mathrm{~mm} ; 0.465 \mathrm{~mm}$ and $0.437 \mathrm{~mm}$, respectively. The Anatolian coast had a mean particle size value of $0.663 \mathrm{~mm}$ and the European coast had a mean particle size value of $0.476 \mathrm{~mm}$. Eceabat had the highest value of sand $(99.59 \%)$ while the lowest value was recorded at Kepez (73.01\%) (Table 3).

Table 3. Sediment characteristics of the sampling points

\begin{tabular}{|c|c|c|c|c|}
\hline Sampling points & Grain size (mm) & Sand content (\%) & Mud (silt+clay) content ( $\%$ ) & Gravel (\%) \\
\hline Gelibolu & 0.636 & 93.22 & 0.44 & 6.30 \\
\hline Çanakkale & 0.364 & 89.76 & 0.05 & 10.19 \\
\hline Eceabat & 0.465 & 99.59 & 0.26 & 0.15 \\
\hline Kilya İnlet & 0.437 & 91.64 & 0.19 & 8.15 \\
\hline Dardanos & 0.342 & 98.91 & 0.77 & 0.32 \\
\hline Lapseki & 1.027 & 97.23 & 0.09 & 2.68 \\
\hline Kilitbahir & 1.046 & 83.11 & 0.13 & 16.75 \\
\hline Kepez & 0.235 & 73.01 & 0.04 & 26.96 \\
\hline
\end{tabular}

Table 4. Total abundance $(\Sigma)$, dominance (Di\%), and frequency of seasonal occurence (f\%) of gastropod species in the study area

\begin{tabular}{|c|c|c|c|}
\hline Species & Abundance $(\Sigma)$ & $\% f$ & $\% D i$ \\
\hline Alvania cimex (Linnaeus, 1758) & 161 & 100 & 3.60 \\
\hline Bela zonata (Locard, 1892) & 26 & 100 & 0.58 \\
\hline Bela nebula (Montagu, 1803) & 19 & 75 & 0.42 \\
\hline Bittium latreillii (Payraudeau, 1826) & 54 & 100 & 1.21 \\
\hline Bittium reticulatum (Da Costa, 1778) & 733 & 100 & 16.39 \\
\hline Bittium scabrum (Olivi, 1792) & 514 & 100 & 11.49 \\
\hline Caecum trachea (Montagu, 1803) & 16 & 75 & 0.36 \\
\hline Cerithium vulgatum Bruguiere, 1792 & 17 & 100 & 0.38 \\
\hline Cerithiopsis minima (Brusina, 1865) & 68 & 100 & 1.52 \\
\hline Cerithiopsis tubercularis (Montagu, 1803) & 1 & 25 & 0.02 \\
\hline Calyptera chinensis (Linnaeus, 1758) & 3 & 25 & 0.07 \\
\hline Conus ventricosus Gmelin, 1791 & 1 & 25 & 0.02 \\
\hline Clanculus cruciatus (Linnaeus, 1758) & 13 & 100 & 0.29 \\
\hline Cyclope neritea (Linnaeus, 1758) & 139 & 100 & 3.11 \\
\hline Epitonium clathrus (Linnaeus, 1758) & 16 & 100 & 0.36 \\
\hline Euspira fusca (Blainville, 1825) & 3 & 50 & 0.07 \\
\hline Gibbula adansonii adansonii (Payraudeau, 1826) & 306 & 100 & 6.84 \\
\hline
\end{tabular}


Gibbula albida (Gmelin, 1791)

Gibbula divaricata (Linnaeus, 1758)

Haminoea hydatis (Linnaeus, 1758)

Jujubinus striatus striatus (Linnaeus, 1758)

Melarhaphe neritoides (Linnaeus, 1758)

Mangelia costata (Donovan, 1804)

Mitrella scripta (Linnaeus, 1758)

Monophorus perversus (Linnaeus, 1758)

Nassarius incrassatus (Stroem, 1768)

Nassarius reticulatus (Linnaeus, 1758)

Ocenebra erinaceus (Linnaeus, 1758)

Rapana venosa (Valenciennes, 1846)

Retusa truncatula (Bruguiere, 1792)

Rissoa membranacea (J. Adams, 1800)

Rissoa splendida Eichwald, 1830

Tornus subcarinatus (Montagu, 1803)

Truncatella subcylindrica (Linnaeus, 1758)
Tricolia pullus pullus (Linnaeus, 1758)

Vexillum ebenus (Lamarck, 1811)

$\begin{array}{lll}18 & 100 & 0.40 \\ 49 & 100 & 1.10 \\ 3 & 75 & 0.07 \\ 21 & 100 & 0.47 \\ 18 & 100 & 0.40 \\ 4 & 50 & 0.09 \\ 1 & 25 & 0.02 \\ 23 & 100 & 0.51 \\ 9 & 75 & 0.20 \\ 238 & 100 & 5.32 \\ 75 & 100 & 1.68 \\ 1 & 25 & 0.02 \\ 18 & 100 & 0.40 \\ 462 & 100 & 10.33 \\ 920 & 100 & 20.57 \\ 84 & 100 & 1.88 \\ 414 & 100 & 9.26 \\ 18 & 100 & 0.40 \\ 6 & 100 & 0.13\end{array}$

\section{Faunal Data}

A total of 36 species and 4472 prosobranch gastropod specimens were collected on the soft bottoms at the Çanakkale Strait (Table 4). Rissoa splendida had the highest dominance value (Di\% $=20.57$ ) followed by the cerithiid Bittium reticulatum $(16.39 \%)$; the lowest dominance value $(0.02 \%)$ was shown by Cerithiopsis tubercularis, Conus ventricosus, Mitrella scripta and Rapana venosa. The highest number of specimens was found during autumn $(n=1501)$ and the lowest during spring period $(n=708)$ (Fig. 2).

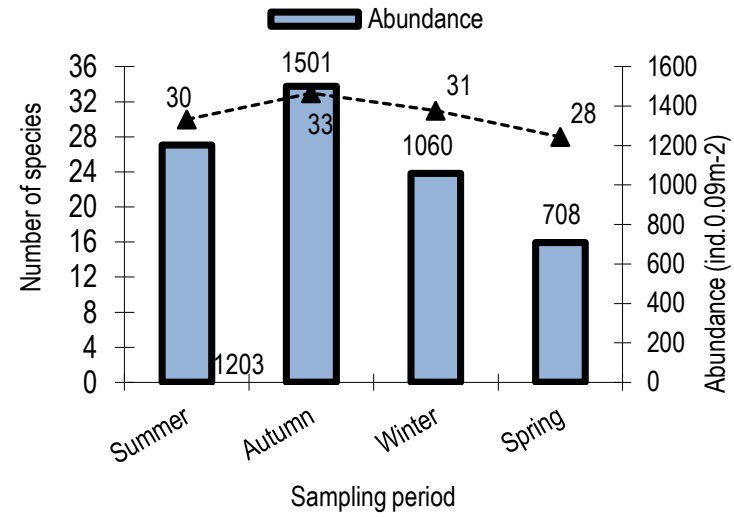

Figure 2. The number of species and individual recorded during the sampling seasons

The highest total number of species and abundance (ind.m2) was recorded at Kilitbahir site ( $S=34 ; n=1069$ ind. $m-2)$ while Lapseki location had the lowest values $(S=16 ; n=157$ ind.m-2) (Fig. 3).

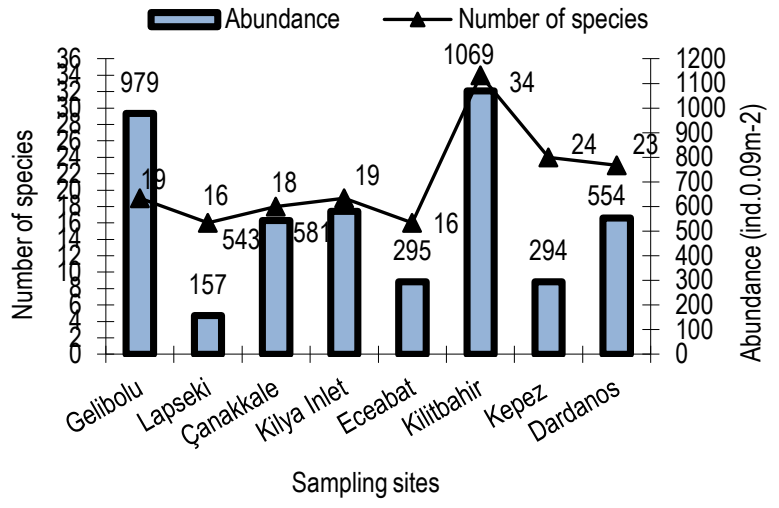

Figure 3. The number of species and specimens found at the sampling points

Shannon-wiener diversity index $\left(\mathrm{H}^{\prime}\right)$ ranged from 1.16 to 1.48. The highest diversity values were in autumn $\left(H^{\prime}=1.46\right)$ and the lowest values were calculated in spring $\left(H^{\prime}=1.38\right)$. Regarding locations, the highest values were observed at Kilitbahir location $\left(H^{\prime}=1.48\right)$ while the lowest values were calculated at Lapseki and Eceabat locations $\left(H^{\prime}=1.16\right)$. The evenness index ranged from 0.94 to 0.98 . Kepez location had the highest evenness value $\left(\mathrm{J}^{\prime}=0.97\right)$ and the lowest value was at Kilya Inlet $\left(\mathrm{J}^{\prime}=0.94\right)$ (Table 5).

Table 5. Diversity index values for the sampling periods

\begin{tabular}{lcc}
\hline Sampling periods & H'$^{\prime}$ & $\mathbf{J}^{\prime}$ \\
\hline Summer & 1.436 & 0.972 \\
Autumn & 1.469 & 0.967 \\
Winter & 1.449 & 0.972 \\
Spring & 1.389 & 0.97 \\
\hline
\end{tabular}


In Bray-Curtis similarity analysis based on the seasons, winter and summer showed the same similarity groups (88.65 \%) (Figure 4).

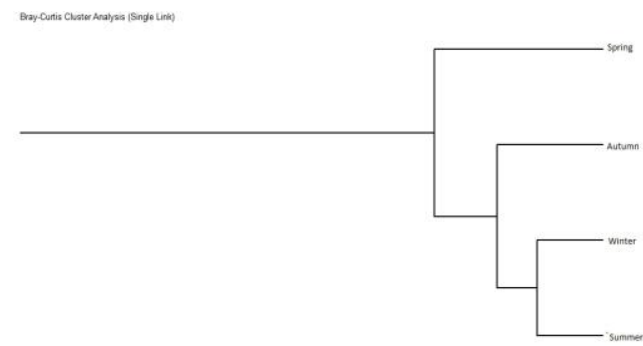

Figure 4. Results of Cluster Analysis based on the Bray-Curtis similarity index for the sampling periods

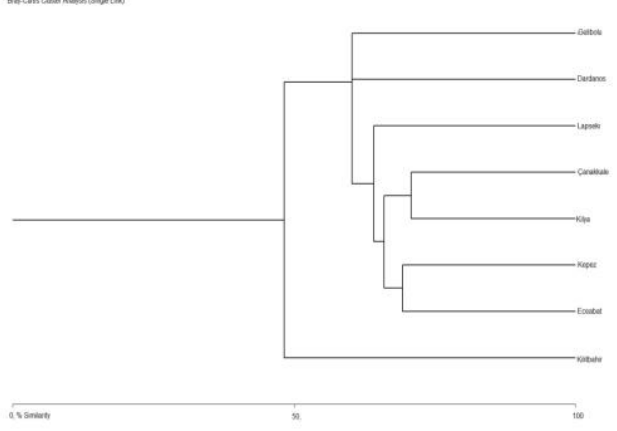

Figure 5. Results of Bray-Curtis Cluster Analysis for the sampling points
Çanakkale and Kilya İnlet sites were the most similar with a similarity value of $70.87 \%$ (Figure 5 ).

According to the sampling depths $(0.5-4 \mathrm{~m})$ the highest number of individuals was recorded at $2 \mathrm{~m}$ in autumn (Figure $6)$.

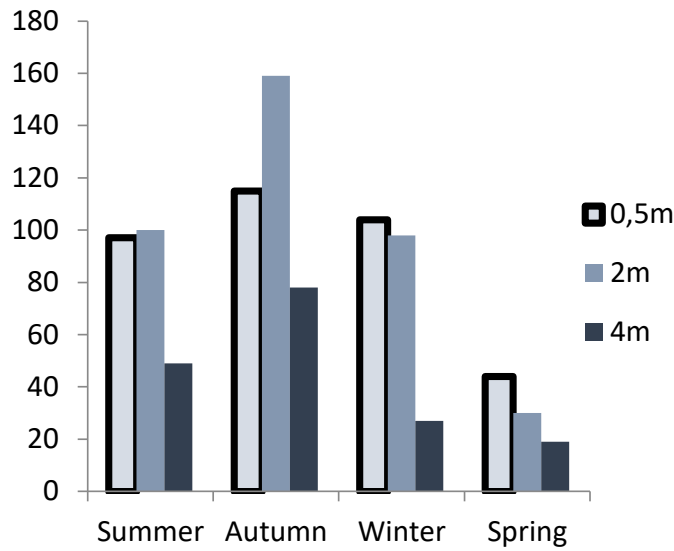

Figure 6. Total abundance at each sampling depth

According to the results of SIMPER Analysis, a total of six species (Bittium reticulatum, Alvania cimex, Gibbula adansonii adansonii, Rissoa membranacea, Rissoa splendida, Tricolia pullus pullus) had an important degree in terms of the sampling location similarity (Table 6).

\section{Correlation with environmental variables}

The relationship between faunal data and environmental variables based on Spearman's rank correlation coefficient was given in Table 7.

Table 6. Results of SIMPER and ANOSIM analysis

\begin{tabular}{|c|c|c|c|c|c|}
\hline \multirow{2}{*}{ Groups } & \multicolumn{3}{|c|}{ SIMPER } & \multicolumn{2}{|c|}{ One-Way ANOSIM } \\
\hline & Average Dissimilarity (\%) & Discriminating species & Contribution (\%) & $R$ value & $P$ value \\
\hline \multirow{2}{*}{ Kepez- Gelibolu } & \multirow{2}{*}{67.5} & Rissoa membranacea & 23.87 & \multirow{2}{*}{1} & \multirow{2}{*}{0.030} \\
\hline & & Tricolia pullus pullus & 14.16 & & \\
\hline \multirow{2}{*}{ Çanakkale-Lapseki } & \multirow{2}{*}{66.21} & Rissoa splendida & 19.84 & \multirow{2}{*}{0.427} & \multirow{2}{*}{0.057} \\
\hline & & Gibbula adansonii adansonii & 13.88 & & \\
\hline \multirow{2}{*}{ Lapseki-Kilitbahir } & \multirow{2}{*}{77.83} & Bittium reticulatum & 12.87 & \multirow{2}{*}{0.895} & \multirow{2}{*}{0.028} \\
\hline & & Alvania cimex & 10.25 & & \\
\hline \multirow{2}{*}{ Gelibolu-Lapseki } & \multirow{2}{*}{76.28} & Rissoa membranacea & 27.02 & \multirow{2}{*}{0.833} & \multirow{2}{*}{0.029} \\
\hline & & Tricolia pullus pullus & 16.31 & & \\
\hline \multirow{2}{*}{ Kilya-Lapseki } & \multirow{2}{*}{63.85} & Rissoa splendida & 24.45 & \multirow{2}{*}{0.354} & \multirow{2}{*}{0.082} \\
\hline & & Bittium reticulatum & 10.98 & & \\
\hline \multirow{2}{*}{ Eceabat-Kilitbahir } & \multirow{2}{*}{68.38} & Bittium reticulatum & 9.76 & \multirow{2}{*}{0.833} & \multirow{2}{*}{0.024} \\
\hline & & Alvania cimex & 9.25 & & \\
\hline \multirow{2}{*}{ Dardanos-Lapseki } & \multirow{2}{*}{68.86} & Tricolia pullus pullus & 20.05 & \multirow{2}{*}{0.760} & \multirow{2}{*}{0.025} \\
\hline & & Rissoa splendida & 12.44 & & \\
\hline
\end{tabular}


Table 7. The results of Spearman's rank correlation coefficient

\begin{tabular}{cccccccc}
\hline & oxygen & abundance & species & pH & particle size & temperature & salinity \\
\hline oxygen & 1 & 0.524 & -0.193 & -0.095 & $.786^{*}$ & -0.595 & -0.548 \\
abundance & 0.524 & 1 & 0.542 & 0.095 & 0.503 & 0.214 & -0.095 \\
species & -0.193 & 0.542 & 1 & 0.41 & 0 & $-747^{*}$ \\
pH & $.786^{*}$ & 0.503 & 0 & -0.086 & 1 & -0.589 & -0.286 \\
particle size & -0.095 & 0.095 & 0.41 & 1 & -0.086 & 1 \\
temperature & -0.595 & -0.214 & -0.024 & -0.286 & -0.589 & 0.238 \\
salinity & -0.548 & 0.095 & $.747^{*}$ & 0.238 & -0.54 & 0.095 \\
\hline
\end{tabular}

*. Correlation is significant at the 0.05 level . ${ }^{* *}$. Correlation is significant at the 0.01 level

The correlation between number of species versus salinity was positive and significantly important $\left(r_{s}=0.78 ; \mathrm{P}<0.05\right)$. A positive correlation between number of species and $\mathrm{pH}\left(r_{s}=\right.$ $0.041 ; P<0.05)$ was found. However, the correlation between temperature and number of species was negative $\left(r_{s}=-0.02 ; P\right.$ $<0.05)$. According to the Spearman's correlation coefficient, the correlation between the particle size $(\mu \mathrm{m})$ and abundance was positive and relatively high $\left(r_{s}=0.52 ; P<0.05\right)$ (Fig. 7), but the correlation between particle size $(\mu \mathrm{m})$ and the species number was very low $\left(r_{s}=0.09 ; P<0.05\right)$.

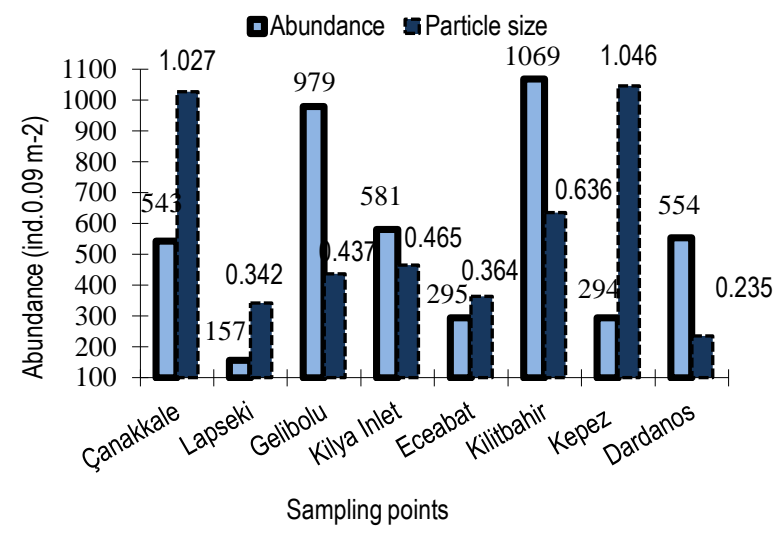

Figure. 7. Particle size and abundance for the sampling points

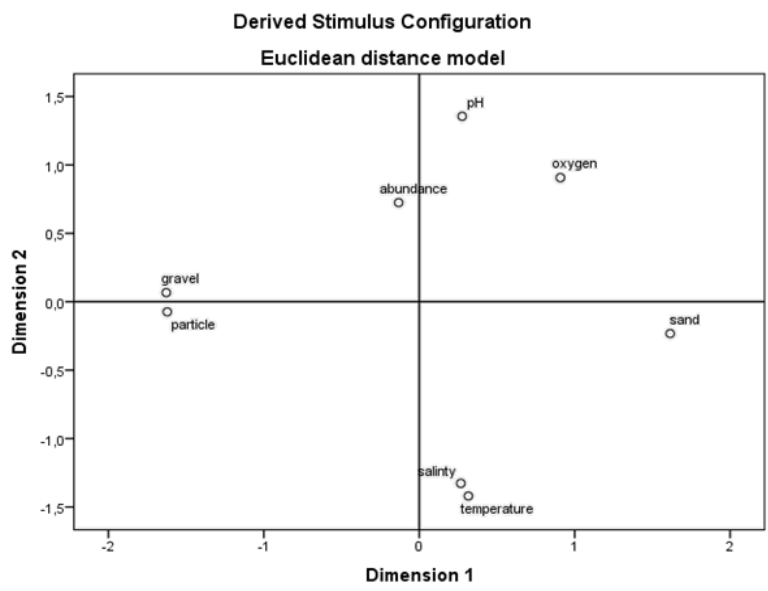

Figure 8. Multidimensional scaling plot showing the similarity among the biological factors
The correlation between the sand content (\%) and total abundance was positive $\left(r_{s}=0.45 ; P<0.05\right)$, whereas the gravel content and abundance was negative $\left(r_{s}=-0.44 ; \mathrm{P}<\right.$ $0.05)$. Chi-square test results showed that the depth was important on the abundance of the species occurrence $(P=$ $0.00, P<0.05)$. According to the results of the MDS analysis, abundance had a positive correlation with temperature and salinity. DO and $\mathrm{pH}$ were related among themselves. Particle size was negatively correlated with abundance (Fig. 8-9).

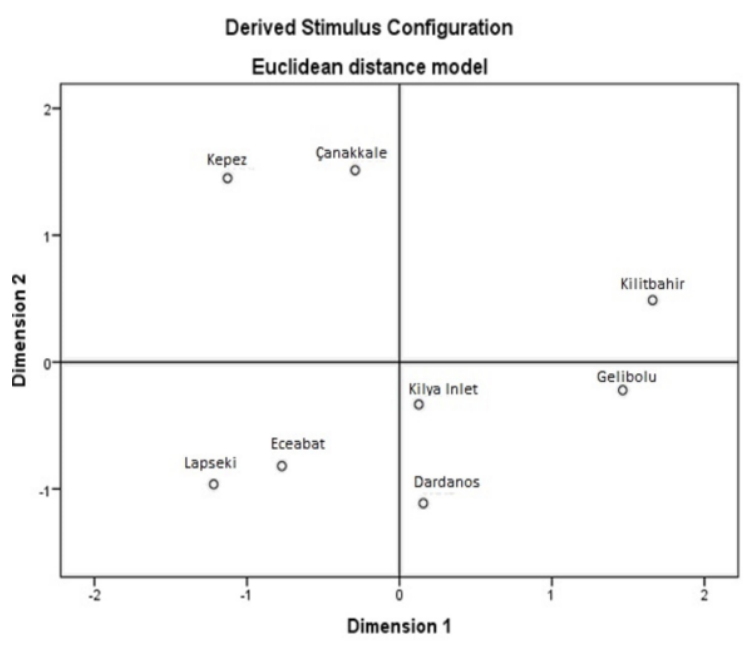

Figure 9. Multidimensional scaling plot showing the similarity among the sampling points

\section{DISCUSSION}

Ecological studies are difficult to carry out in marine areas because of the complexity of factors, environmental and anthropogenic, that dominate the ecosystem. These factors cause pressure on benthic communities in severeal functions, for example, some species can be disturbed and cannot develop naturally, impose an opportinistic behavior and become less competitive (Glemarec, 1993). The distribution of populations in marine ecosystems is dependent on the environmental factors such as temperature, salinity, and sediment characteristics (Afli et al., 2008). Molluscs are used as indicators to compare the differences between ecosystems and they play important roles on the benthic biota (Zenetos, 1996). Soft bottom benthic habitats can be classified based on 
the community diversity index as bad $\left(0<\mathrm{H}^{\prime} \leq 1.5\right)$, poor $(1.5$ $\left.<\mathrm{H}^{\prime} \leq 3\right)$, moderate $\left(3<\mathrm{H}^{\prime} \leq 4\right)$, good $\left(4<\mathrm{H}^{\prime} \leq 5\right)$ and high $\left(\mathrm{H}^{\prime}>\right.$ 5) (Simboura and Zenetos, 2002). In a study, Koutsoubas et al. (2000) found that the diversity index $\left(\mathrm{H}^{\prime}\right)$ values in Giolova Lagoon (southwestern Greece) changed between 0.75 and 2.35. In their study, they have reported 18 gastropoda species inwhich Gibbula adansonii, Gibbula divaricata, Cerithium vulgatum, Bittium reticulatum, Cyclope neritea and Nassarius incrassatus also showed distribution in our study. Dimitriadis and Koutsoubas (2008) recorded a diversity index ( $\left.\mathrm{H}^{\prime}\right)$ of 1.50 in Gera Gulf of Lesvos and they have reported 45 gastropod species. Albayrak et al., (2007) reported H' values as 2.5-5 in Edremit Bay. In the present study, unlike the ones mentioned above the diversity index was low $\left(H^{\prime}=1.35-1.50\right)$. Therefore, according to the above classification our sampling locations can be considered as "poor".

Relationship between the distribution of benthic communities on/in soft bottoms and sediment characteristics has been studied for decades (Lu, 2005). Physical unrest and chemical contamination in sediment may have higher effects on macrobenthic community structure than sediment characteristics at coastal waters (Gray, 1997; Snelgrove et al., 1997). The distribution of macrobenthic communities in marine ecosystems is highly correlated with the type of sediment, which is related to a wider set of environmental conditions (Hoey, 2004). In the present study, particle size distribution of the sediment and the species number showed low correlation (rs= 0.52; $P<0.05$ ). On the contrary, Albayrak et al., (2007) determined a positive correlalation between particle size and number of individuals as well as number of species from Edremit Bay (the northeastern Aegean Sea). This could be attributed to the substrate characteristics and hydrodinamic forces leading to the benthic community structure in the shallow waters of the Aegean Sea (Albayrak et al., 2007).

Rueda et al. (2008) found high number of species of Jujubinus striatus $(\mathrm{N}=173)$ at a sampling point with a mud content of $13.4 \%$. Argyrou et al. (1999) recorded 11 gastropoda species in a $95 \%$ sandy bottom. Cerithium vulgatum, Conus ventricosus and Bela nebula were also found in this study. Lourido et al. (2006) studied the molluscan assemblages of soft bottom in the Ria de Aldan (the northwestern Spain) and recorded the mean sand content as $86.5 \%$ for a depth of $4 \mathrm{~m}$. Moreover, same authors reported the mean species number as 29. Similar to their study, Caecum trachea, Nassarius reticulatus, Bittium reticulatumalso showed distribution according to the sediment characteristics in the present study. In a study, Koutsoubas et al. (2000) found a total number of 60 gastropoda species at $40 \mathrm{~m}$ depth in the Cretan Sea (the eastern Mediterranean) and they stated that Bittium reticulatum, Calyptera chinensis, Euspira fusca and Retusa truncatula occurred in dense abundances at $40 \mathrm{~m}$ depth. In the present study these species were also recorded from the coastal waters of Çanakkale Strait.

Dimitriadis and Koutsoubas (2008) performed a study on the molluscans of Gera Bay (Lesvos, the northeast Aegean
Sea) and recorded a total of 45 gastropod species. Albayrak et al. (2007) reported a total of 13 species of molluscs in Edremit Bay (the norteastern Aegean Sea). Çınar et al. (2008) carried out a study on macrobenthos of Alsancak Harbour, Izmir Bay (the eastern Aegean Sea) and found totally 62 species of molluscs from the area. Recently, Bitlis et al. (2010) reported 62 species belonging to gastropods in the Sea of Marmara coast. Bittium scabrum was the dominant species (Di \% = 27) in the study (Bitlis et al., 2010). Dogan et al. (2005) found a total of 6 gastropod species on the soft bottoms of Izmir Bay (the eastern Aegean Sea). We found Calyptera chinensis, Monophorus perversus and Cyclope neritea in our study and these species were also reported by Dogan et al., (2005). Çınar et al., (2012) conducted a seasonal study between the depths of $19 \mathrm{~m}$ and $67 \mathrm{~m}$ in İmir Bay and they recorded 68 gastropoda species. Palaz and Colakoglu (2009) studied macrozoobenthic diversity in the Çanakkale Strait and reported only $B$. reticulatum and $C$. neritea in their study. Aslan-Cihangir and Ovalis (2013) conducted a study in the Çanakkale Strait between the depths of $10 \mathrm{~m}$ and $83 \mathrm{~m}$ and recorded 191 gastropoda species. Additionally, Bittium reticulatum had the highest number of individuals in the same study. During this study, a total of 36 species and 4472 individulas belonging to gastropoda were found from the Çanakkale Strait coastal waters.

The community structure of molluscs can be influenced by biological and physicochemical factors. The factors such as sediment particle size, salinity, $\mathrm{pH}$, depth, nutrients, food sources, and pollution affect the community structure (Rumisha et al., 2012).

In this study Rissoa splendida was found to be the most abundant species and it was followed by Bittium reticulatum (Di $\%=16.39)$. Dense population of $R$. splendida and $B$. reticulatum were presented in previous works (Öztürk, 2001; Albayrak et al., 2007; Çulha et al., 2007; Mutlu and Ergev, 2008; Bitlis et al., 2010; Çulha et al., 2010; Aslan-Cihangir and Ovalis 2013) carried out on the Turkish coasts.

Rueda and Salas (2003) indicated that Jujubinus striatus (Di \% $=30.15)$, Tricolia pullus (Di $\%=14.41$ ) and Nassarius incrassatus (Di \% $=0.72$ ) were dense in Caulerpa prolifera meadows. Yet, we noted that this species created a dense population on the soft bottoms as well. Jujubinus striatus generally prefers Zostera marina meadows (Rueda et al., 2001). Arrayo et al., (2006) found dense populations (Di \% = 71.8) of Jujubinus striatus in Z. marina beds at the depth of 14$16 \mathrm{~m}$ Alboran Sea (the southern Spain). In the present study, we recorded a $0.47 \%$ dominance value of $J$. striatus. Recently, Moreira et al., (2010) reported 4 species of Rissoidae and Trochidae in subtidal sandy sediments of Iberian Peninsula. In this study, we recorded 5 species from Trochidae and 4 species from Rissoidae.

Studies showed that changes in salinity and temperature may affect the community structure as well as species diversity. 
According to Albayrak et al., (2007) the salinity values were between $37.7 \mathrm{ppt}$ and $37.9 \mathrm{ppt}$ at the depths of $1-20 \mathrm{~m}$ in Edremit Bay. In the same study temperature values were measured between 18.8 and $1.6^{\circ} \mathrm{C}$. Dogan et al., (2005) noted that salinity and temperature values were between 32.1 and 39.8 ppt and between 12 and $25.1^{\circ} \mathrm{C}$, respectively for İzmir Bay (the eastern Aegean Sea). Recently, Albayrak et al., (2010) found salinity levels as 22-25 ppt at 1-10 m depths of the Sea of Marmara. In our study area, we determined quite similar measurement values regarding salinity and temperature to Albayrak et al., (2010).

The Çanakkale Strait plays an important role in the water mass exchange through the Aegean -Black Sea System. The dynamics of the Çanakkale Strait depend on the turbulent friction (Kanarska and Maderich, 2008) and the area is swept by currents, the soft bottoms may contain some small

\section{REFERENCES}

Afli, A., Ayarı, R. \& Zaabi, S. (2008). Ecological quality of some Tunisian coast and lagoon locations, by using benthic community parameters and biotic indices. Estuarine, Coastal and Shelf Science, 80, pp: 269-280 doi: 10.1016/j.ecss.2008.08.010

Albayrak, S., Balkıs, H., Zenetos, A., Kurun, A. \& Kubanç, C. (2006). Ecological quality status of coastal benthic ecosystems in the Sea of Marmara. Marine Pollution Bulletin, 52:790-799 doi: 10.1016/j.marpolbul.2005.11.022

Albayrak, S., Balkıs, H. \& Çınar, M.E. (2007). Shallow-water soft bottom macrozoobenthic communities from Edremit Bay (NE Aegean Sea). Belgian Journal of Zoology, 137(2): 127-132.

Albayrak, S. \& Çağlar, S. (2010). Three Bivalve Species New To The Turkish Levantine Sea, IUFS Journal of Biology, 69: 107-110.

Argyrou, M., Demetropoulos, A. \& Hadjichristophorou, M. (1999). Expansion of the Macroalga Caulerpa racemosa and Changes in Softbottom Macrofaunal Assemblages in Moni Bay, Cyprus. Oceanologica Acta. 22(5): 517-528. doi: 10.1016/S0399-1784(00)87684-7

Arrayo, M.C., Salas, C., Rueda, J.L. \& Gofas, S. (2006). Temporal changes of mollusc populations from a Zostera marina bed in Southern Spain (Alboran Sea), with Biogeographic Considerations. Marine Ecology, 27: 417-430 doi: 10.1111/j.1439-0485.2006.00117.x

Aslan-Cihangir, H. \& Ovalis, P. (2013). Seasonal variations and structure of the molluscan assemblage in the Çanakkale Strait (Turkey). Acta zoologica Bulgarica, 65 (2): 233-250.

Barash, A. \& Danin, Z. (1992). Fauna Palestina, Mollusca I, Annotated list of Mediterranean Molluscs of Israel and Sinai, The Israel Academy of Sciences and Humanities, Jerusalem, 405p.

Bitlis, B., Öztürk, B., Doğan, A. \& Önen, M. (2010). Marmara Denizi kıyılarında dağılım gösteren bazı mollusca türlerinin sistematik ve ekolojik özellikleri. Marmara Denizi Sempozyumu, 253-265 p.

Bouchet, P. \& Rocroi, J.P. (2005). Classification and Nomenclature of Gastropod Families. Malacologia 47(1-2): 1-397.

Buchanan, J.B. (1984). Sediment analysis. In: (eds. N.A. Holme \& A.D Mclntyre) methods for the study of marine benthos 2 nd ed. Blackwell, Oxford, 41-65.

Butakov, E. A., Chuchin, V. D., Cherkasova, M. B. \& Lelekov, S.G. (1997) Determinator of Gastropoda of the Black Sea. IBSS, NASU, Sevastopol, $127 \mathrm{p}$.

Cachia, C., Misfud, C. \& Sammut, P.M. (1996). The Marine Mollusca of the Maltase Islands, Part. 2, Neotaenioglossa, Backhuys Publishers, Leiden, Netherlands, 1-228 p. aggregates of stones, or pebbles, which function as a substrate for the species found in the sampling area.

Our data was very scarce in terms of gastropod fauna of the area since the sampling depths were quite shallow. However, this study has made a contribution in terms of community structure and species composition on soft-bottoms of the shallow waters of the Çanakkale Strait which has not been studied previously. Moreover, in this study the relationships between the community structure and the environmental variables were also presented which in turn may have significant effects on species diversity.

\section{ACKNOWLEDGEMENTS}

The material of this study was obtained by the financial support of Scientific and Technological Research Council of Turkey CAYDAG 107 Y332 code Project.

Cachia, C., Misfud, C. \& Sammut, P.M. (2001). The Marine Mollusca of the Maltase Islands, Part. 3, Sub-class Prosobranchia to sub-class Pulmonata, order Basommatophora, Backhuys Publishers, Leiden, Netherlands, $266 p$.

Çınar, M.E., Katagan, T., Öztürk, B., Egemen, Ö., Ergen, Z., Önen, M., Kirkim F., Bakir, K., Kurt, G. \& Dagli, E. (2006). Temporal Changes of Soft-bottom Zoobenthic Communities in and Around Alsancak Harbor (İzmir Bay, Aegean Sea), With Special Attention to the Autecology of Exotic Species. Marine Ecology, 27(3): 229-246 doi: 10.1111/j.1439-0485.2006.00102.x

Çınar. M.E., Katagan, T., Öztürk, B., Bakır, K., Daglı, E., Açık, S., Dogan, A. \& Bitlis, B. (2012). Spatio-temporal distributions of zoobenthos in soft substratum of İzmir Bay (Aegean Sea, eastern Mediterranean), with special emphasis on alien species and ecological quality status. Journal of the Marine Biological Association of the United Kingdom, 92(7): 14571477 doi: $10.1017 /$ S0025315412000264.

Çulha, M., Bat, L. \& Türk Çulha, S. (2007). On The Presence of Melarhaphe neritoides (Linnaeus, 1758) (Prosobranchia, Gastropoda, Mollusca) In the Sinop Peninsula (Central Black Sea, Turkey). Journal of Applied Biological Sciences, 1(2): 41-43.

Dimitriadis, C. \& Koutsoubas, D. (2008). Community properties of benthic molluscs as indicators of enviromental stres induced by organic enrichment. Journal of Natural History 42(5-8): 559-574 doi: 10.1080/00222930701835530

Doğan, A., Çınar, M.E., Önen, M., Ergen, Z. \& Katağan, T. (2005). Seasonal Dynamic of Soft Bottom Zoobenthic Communities in Polluted and Unpolluted Areas of İzmir Bay (Aegean Sea). Senckenbergiana maritima, 35(1): 133-145.

Feld, C. K. \& Hering, D. (2007). Community structure or function: effects of environmental stress on benthic macroinvertebrates at different spatial scales. Freshwater Biol 52: 1380-1399 doi: 10.1111/j.1365-2427.2007.01749.x

Glamarec, M. (1973). The benthic communities of European North Atlantic continental shelf. Oceanography and Marine Biology: An Annual Review $11,263-289$

Graham, A. (1971). British Prosobranch and other Operculate Gastropod Molluscs, Academic Press, $112 \mathrm{p}$.

Gray, J.S. (1981). The ecology of marine sediments. Cambridge University Press. Cambridge.

Grillo, M.C.G., Ventura, C.R., DA \& Silva S.G.H. (1998). Spatial distribution of bivalvia (Mollusca) in the soft-bottoms of llha Grande Bay, Rio de Jenerio, Brazil Revista Brasileira de Oceanografia, 46: 19-31. 
Hoey, G. V., Degraer, S. \& Vincks, M. (2004). Macrobenthic community structure of soft bottom sediments at the Belgian Continental Shelf. Estuarine, Coastal and Shelf Science 59: 599-613. doi:10.1016/j.ecss.2003.11.005

Huston, M.A. (1994). Biological diversity. The coexistence of species on changing landscapes. Cambridge University Press, Cambridge.

Kanarska, Y. \& Maderich, M. (2008). Modelling of seasonal exchange flows through the Çanakkale Strait Strait. Estuarine, Coastal and Shelf Science, 79: 449-458 doi:10.1016/j.ecss.2008.04.019

Kelaher, B.P. \& Levinton, J.S. (2003). Variation in detrial enrichment causes spatio-temporal variation in soft sediment assemblages. Marine Ecology Progress Series, 261: 85-97.

Koutsoubas, D., Arvanitidis, C., Dounas, C. \& Drummond, L. (2000) Community structure and dynamics of the Molluscan Fauna in a Mediterranean lagoon (Giolova lagoon, SW Greece). Belgian Journal of Zoology, 130 (1): 131-138.

Koutsoubas, D., Tselepides, A. \& Eleftheriou, A. (2000). Deep Sea Molluscan Fauna of the Cretan Sea (Eastern Mediterranean): Faunal, Ecological and Zoogeographical Remarks. Senckenbergiana maritima, 30(3/6): 85-98.

Lourido, A., Gestoso, L. \& Troncoso, J.S. (2006). Assemblages of the Molluscan Fauna in Subtidal Soft Bottoms of the Ria de Aldán (Northwestern Spain). Journal of the Marine Biological Association of the United Kingdom 86: 129-140.

Lu, L. (2005). The relationship between soft-bottom macrobenthic communities and environmental variables in Singaporean waters. Marine Pollution Bulletin 51(8-12): 1034-1040. doi: 10.1016/j.marpolbul.2005.02.013

Moreira, J., Aldea, C. \& Troncoso, J.S. (2010). Temporal Dynamics of Gastropod Fauna on Subtidal Sandy Sediments of the Ensenada de Baiona (NW Iberian Peninsula). Helgol Mar Res 64: 311-320 doi: 10.1007/s10152-009-0186-3

Mutlu, E. \& Ergev, M.B., (2008). Spatio-temporal Distribution of Soft-bottom Epibenthic Fauna on the Cilician Shelf (Turkey), Mediterranean Sea. Revista de Biología Tropical 56 (4): 1919-1946.

Nordsieck, F. (1977). The genus Bittium LEACH, 1847, in the European Seas, pp: 6-9.

Öztürk, B. (2001). Turridae Swainson, 1840 Species (Gastropoda-Mollusca) of İzmir Bay (Aegean Sea). Turkish Journal of Zoology, 25: 53-56.
Palaz, M. \& Colakoglu, S. (2009). Macrozoobenthic diversity of the Çanakkale Strait. Journal of Animal and Veterinary Advances 8 (11): 2341-2344.

Pielou, E.C. (1975). Ecological diversity. A Wiley-Inter Science Publication, London.

Rueda, J.L., Fernández-Casado, M., Salas, C. \& Gofas, S. (2001). Seasonality in a Taxocoenosis of Molluscs From Soft Bottoms in the Bay of Cádiz (Southern Spain). Journal of the Marine Biological Association of the United Kingdom, 81(6): 903-912.

Rueda, J.L. \& Salas, C. (2003). Seasonal Variation of a Molluscan Assemblage Living in a Caulerpa prolifera Meadow within the Inner Bay of Cádiz (SW Spain). Estuarine Coastal Shelf Science, 57 (5): 909-918.

Rueda, J.L., Marina, P., Salas, C., Urra, J. (2008). Jujubinus striatus striatus (Linneaus, 1758) (Gastropoda: Trochidae) From a Deep Zostera marina Bed in Southern Spain (Alboran Sea): Aspects of Ecology and Biology. Journal of Molluscan Studies, 74 (4): 345-354.

Rumisha, C., Elskens, M., Leemakers, M. \& Kochzius, M. (2012). Trace metal pollution and its influence on the community structure of soft bottom molluscs in interdial areas of the Dar es Salaam coast, Tanzania. Marine Pollution Bulletin, 64: 521- 531. doi:10.1016/j.marpolbul.2011.12.025

Sabelli, B., Giannuzzi-Savelli, R. \& Bedulli, D. (1992). Catalogo Annotato dei Molluschi Marini del Mediterraneo, Vol 2. Libreria Naturalistica Bolognese, Bologna, $150 \mathrm{p}$.

Shannon, C. E. \& Weaver, W. (1963). The Mathematical Theory of Communications. University of Illinois Press, Urbana, Illinois, $117 \mathrm{p}$.

Simboura, N. \& Zenetos, A. (2002). Benthic indicators to use in ecological quality classification of Mediterranean soft bottoms marine ecosystems, including a new biotic index. Mediterranean Marine Science 3(2): 77-111. doi: $10.12681 / \mathrm{mms} .249$

Snelgrove, P.V.R. (1998). The biodiversity of macrofaunal organisms in marine sediments. Biodiversity Conservation. 7(9): 1123-1132. doi:10.1023/A:1008867313340

Taylor, J. D., Noel, J., Morris \& Taylor, C.N. (1980). Food specialization and the evolution of predatory prosobranch gastropods. Palaentology, Vol. 23(2): 375-409.

Zenetos, A. (1996). FAUNA GRAECIAE VII. The marine Bivalvia (Mollusca) of Greece.Hellenic Zoological Society and NCMR, Athens: NCMR. 